RYSZARD ZIĘBA

Uniwersytet Warszawski

DOI : $10.14746 /$ rie.2017.11.6

\title{
Promocja demokracji przez Zachód we wschodniej części Europy w XXI wieku
}

Państwa zachodnie i ich instytucje międzynarodowe kontynuowały w XXI wieku politykę promowania demokracji, rządów prawa, praw człowieka i gospodarki rynkowej wobec byłych państw socjalistycznych na terenie byłego ZSRR oraz Bałkanów. Polityka ta miała oparcie w demokratycznym ustroju państw zachodnich i przyjętej liberalno-idealistycznej ideologii, zakładającej, że wartości leżące u jej podstaw powinny być zaakceptowane przez wszystkie kraje europejskie i przyległego regionu Azji Środkowej. Widzimy w tym ideę głoszoną na progu epoki pozimnowojennej przez amerykańskiego politologa Francisa Fukuyamę (1992), który obwieścił wówczas ,koniec historii” po upadku komunizmu i nastanie ery demokratycznego kapitalizmu i ideologii liberalnej. Szybko ten pogląd został poddany testowi w transformujących się krajach wschodniej części Europy, gdzie pojawiły się koncepcje i poglądy populistyczne, nacjonalistyczne i konserwatywne. Wybitny socjolog niemiecki Ralph Darendorf (1990) dostrzegał nawet widmo autorytaryzmu i dyktatur w postkomunistycznej Europie. Tendencje takie pojawiły się Rumunii, na Słowacji, w Serbii, na Białorusi a nawet w mniejszym stopniu w Polsce w pierwszej połowie lat 90. XX wieku. Ponowny ich renesans zaznaczył się po przystąpieniu części tych państw do Unii Europejskiej, po 2004 roku. Wówczas tendencje populistyczne, konserwatywne i nacjonalistyczne wystapiły w polityce państw Grupy Wyszehradzkiej, na Węgrzech, w Polsce, na Słowacji i w Republice Czeskiej. Dla Zachodu najważniejsze znaczenie miało promowanie demokracji w państwach leżących na Bałkanach Zachodnich i na obszarze poradzieckim.

Państwa zachodnie, dysponując grupowymi organizacjami w postaci NATO i Unii Europejskiej uważają, że u podstaw trwałego pokoju leży demokratyczny ustrój, respektowanie praw człowieka oraz gospodarka rynkowa. W preambule Traktatu Północnoatlantyckiego zapisano, że jego sygnatariusze będą ochraniać wolność, wspólne dziedzictwo i dorobek cywilizacyjny swoich narodów, oparte na zasadach demokracji, wolności jednostki i rządów prawa. Podejmując politykę rozszerzania na wschód zadeklarowały, że zmierzają do poszerzania strefy demokracji i stabilności w Europie. Natomiast Unia Europejska oparła się na przekonaniu, jakie legło u podstaw procesu integracji europejskiej na początku lat 50. XX wieku, że integracja ekonomiczna ma kluczowe znaczenie dla zapewnienia pokoju w ciężko doświadczonej wojnami Europie. Następnie dodano katalog norm i wartości demokratycznych jako warunek tego pokoju. Po zimnej wojnie Unia Europejska przyjęła koncepcję „Wider Europe”, którą zaczęła realizować zawierając ze wschodnimi sąsiadami układy stowarzyszeniowe, prowadząc Europejską Polityką Sąsiedztwa i Partnerstwo Wschodnie oraz przyjmując do swojego grona nowych członków. U podstaw tej polityki leży zasada warun- 
kowości, która zakłada, że Unia oferuje partnerom określone korzyści w zamian za spełnienie kryteriów politycznych i ekonomicznych, sprowadzanych do zapewnienia demokracji i gospodarki rynkowej (Beichelt, 2012, s. 5-6)1. W odniesieniu do państw Europy Środkowej i Wschodniej oraz kandydatów do członkostwa w UE sformułowano w 1993 r. tzw. kryteria kopenhaskie. Zawierają się one w następującym stwierdzeniu Rady Europejskiej z czerwca 1993 r.: „Członkostwo wymaga, aby kraj kandydujący osiagnął stabilność instytucji gwarantujących demokrację, rządy prawa, prawa człowieka i ochronę mniejszości, istnienie i funkcjonowanie gospodarki rynkowej, jak też zdolność radzenia sobie z presją konkurencyjności i sił rynkowych w ramach Unii. Członkostwo implikuje zdolność kandydata do przyjęcia zobowiązań członkostwa, włączając cele unii politycznej, gospodarczej i monetarnej" (Presidency Conclusions, 1993, s. 13). Kryteria te dobitnie wyrażają warunki, które stwierdzają, że przyszłe członkostwo państw kandydujących do Wspólnoty zależy od spełnienia kryteriów politycznych i ekonomicznych. Ta polityka zakłada budowanie wspólnoty bezpieczeństwa, na wzór tej, jaką proponował w 1957 r. Karl Deutsch.

Unia Europejska dysponuje kilkoma instrumentami promowania demokracji. Do nich można zaliczyć pomoc rozwojową, zwykłą współpracę z podmiotami zewnętrznymi, finansowanie projektów w ramach Europejskiej Inicjatywy na Rzecz Demokracji i Praw Człowieka (EIDHR), umowy o partnerstwie oraz sankcje polityczne i ekonomiczne. Unia wykorzystuje te cywilne instrumenty w swoich stosunkach zewnętrznych, bilateralnych i wielostronnych, z krajami trzecimi (Kotzian, Knodt, Urdze, 2011, s. 995 i n.). Wprawdzie UE dokonuje także eksportu swoich wartości, promowania demokracji, praw człowieka i rządów prawa poprzez zaangażowanie w celach zapobiegania konfliktom, reagowania kryzysowego oraz odbudowy i budowania pokoju po konfliktach, ale ta druga grupa jej działań jest spójna z tożsamością Unii jako „mocarstwa cywilnego", o czym decydują pokojowe środki zarządzania kryzysowego, multilateralizm i dbałość o przestrzeganie prawa międzynarodowego. To pozwala twierdzić, że Unia Europejska jest przede wszystkim „cywilnym mocarstwem” (Börzel, Risse, 2009, s. 25) lub „normatywnym mocarstwem”, ani cywilnym ani militarnym (Manners, 2001). Rozbudowane instrumenty promowania demokracji za granica, choć z wyraźną przewagą środków siłowych, stosują Stany Zjednoczone Ameryki. Mocarstwo to od początku lat 90. XX wieku w swoich koncepcjach polityki zagranicznej umieszcza promowanie demokracji wśród naczelnych celów i wiąże to z działaniami na rzecz zapewnienia swojego bezpieczeństwa narodowego (Zając, 2008).

Ważną instytucją międzynarodową stworzoną przez państwa zachodnie jest powołana do życia w 2000 r. na konferencji ministerialnej w Warszawie Wspólnota Demokracji (Community of Democracies). Jest ona globalną międzyrządową koalicją państw demokratycznych, której celem jest promowanie demokracji oraz wzmacnianie demokratycznych norm i instytucji na całym świecie. Jej pomysłodawcami i inicjatorami konferencji byli ówczesny minister spraw zagranicznych Polski Bronisław Geremek oraz była sekretarz stanu USA Madeleine Albright. Podstawą Wspólnoty stała się, podpisana przez przedstawicieli 106 państw, deklaracja „Ku Wspólnocie Demokracji”. W Warszawie ma swoją siedzibę Stały Sekretariat Wspólnoty Demokracji.

${ }^{1} \mathrm{~W}$ literaturze przedmiotu rozróżnia się cztery modele promowania demokracji na zewnątrz: a) przymus, b) warunkowość, c) perswazję, d) socjalizację (Beichelt, 2012, s. 4-12). 
W ramach Wspólnoty Demokracji są uzgadniane konkretne projekty służące wsparciu reform demokratycznych i rozwoju społeczeństwa obywatelskiego w tym m.in. w państwach poradzieckich. Na tym kierunku geograficznym mocno angażuje się Polska, która w marcu 2011 r. uruchomiła Polsko-Amerykański Dialog Strategiczny na rzecz Demokracji. Polska stara się przekazywać doświadczenia ze swojej ponad dwudziestoletniej transformacji ustrojowej. Doprowadziła nawet do stworzenia (w marcu 2013 r.) Europejskiego Funduszu na rzecz Demokracji (European Endowment for Democracy, EED). Ma on promować wspieranie reform demokratycznych i budowanie społeczeństwa obywatelskiego w całym sąsiedztwie UE.

\section{Bałkany Zachodnie}

Ważną grupę adresatów prowadzonej przez Zachód polityki promowania demokracji stanowią państwa powstałe po rozpadzie Jugosławii i Albania. Unia Europejska była zainteresowana w stabilizacji tych krajów, ogarniętych w latach 90. wojnami domowymi. Chociaż te wojny zakończyły się porozumieniami pokojowymi z Dayton w 1995 r. i innymi kończącymi interwencję NATO w 1999 r., to jednak kraje tej części Europy nadal pozostały „Bałkańskim kotłem” mogącym wybuchnąc przy sprzyjającej okazji. ONZ, OBWE i Unia Europejska włączyły się w „budowanie pokoju po konflikcie" w tych krajach, a jako najlepszą drogę do tego celu wybrały umacnianie rządów prawa i instytucji demokratycznych, a przy współudziale międzynarodowych donatorów prowadziły także rekonstrukcję gospodarek w oparciu o wartości rynkowe (Drygiel-Bielińska, 2016, s. 161-163). Dla Unii Europejskiej jest to szczególnie ważne zadanie, jako, że chodzi o kraje z nią sąsiadujące i mające aspiracje europejskie.

Temu służyły zainaugurowane w 1999 roku Pakt Stabilności dla Europy Południowo-Wschodniej i Proces Stabilizacji i Stowarzyszenia (SAP). Ten drugi ma przede wszystkim na celu integrację tych państw z UE. Zgodnie ze stosowaną przez UE zasadą warunkowości osiagnięcie postępu w reformach politycznych i ekonomicznych przez poszczególne kraje bałkańskie premiowano zawieraniem umów o stabilizacji i stowarzyszeniu. Istotną cechą tych umów było zobowiązanie ich sygnatariuszy do zawierania porozumień o współpracy regionalnej i ustanawiania stref wolnego handlu pomiędzy nimi. 24 listopada 2000 r. odbyło się spotkanie na szczycie przywódców państw UE i Bałkanów Zachodnich w stolicy Chorwacji Zagrzebiu. Postanowiono organizowanie regularnych spotkań na szczeblu ministerialnym pomiędzy UE a państwami uczestniczącymi w SAP oraz zainicjowano program pomocy technicznej i finansowej CARDS (Community Assistance for Reconstruction, Development and Stabilisation) na lata 2001-2006, zastapiony od 2007 r. przez Instrument Pomocy Przedakcesyjnej (IAP). To spotkanie stworzyło także impuls do rozpoczęcia w $2002 \mathrm{r}$. tzw. procesu zagrzebskiego (The Zagreb Process), którego celem było wzmocnienie mechanizmów politycznego dialogu oraz współpracy regionalnej pomiędzy UE a państwami Bałkanów Zachodnich. Następnie w maju 2003 r. Komisja Europejska zainicjowała Nowe Partnerstwo na rzecz Integracji Bałkanów Zachodnich z UE. W ten sposób potwierdzono, że SAP pozostanie głównym instytucjonalnym forum współpracy UE z państwami Bałkanów Zachodnich, a wzmocnieniu ulegną stopniowe przyjmo- 
wanie acquis communautaire, współpraca w zakresie Wspólnej Polityki Zagranicznej i Bezpieczeństwa UE oraz spraw wewnętrznych i wymiaru sprawiedliwości, a także zwiększone uczestnictwo w różnych programach UE, zwłaszcza w zakresie edukacji (Górka-Winter, 2003; Zięba, 2007, s. 148-156).

Postępy w demokratyzacji krajów Bałkanów Zachodnich zostały docenione przez Komisję Europejską, która 26 marca 2003 r. zaproponowała przystąpienie do UE Albanii, Bośni i Hercegowinie, Chorwacji, byłej Jugosłowiańskiej Republice Macedonii oraz Serbii i Czarnogórze, zaś w maju 2003 r. zainicjowała nowe „Partnerstwo na rzecz Integracji Bałkanów Zachodnich z UE”, a w czerwcu 2003 r. Rada Europejska na spotkaniu w Salonikach potwierdziła, że wszystkie kraje objęte Procesem Stabilizacji i Stowarzyszenia stały się potencjalnymi kandydatami do członkostwa w UE. Od maja 2007 r. Pakt Stabilności został włączony w ramy uruchomionego w poprzednim roku szerszego Procesu Współpracy w Europie Południowo-Wschodniej (SEECP), a od lutego 2008 r. jego działania kontynuuje Regionalna Rada Partnerstwa. Jest ona finansowana po $1 / 3$ przez Unię Europejską, państwa regionu i donatorów zewnętrznych.

Unia Europejska w swojej polityce wobec Bałkanów Zachodnich podejmuje wiele działań równoległych w zakresie promocji demokracji i rządów prawa, wspomagających reformy rynkowe i rozwój gospodarczy, zachęca państwa całych Bałkanów (łącznie z Rumunią, Bułgarią i Turcją) do rozwijania współpracy regionalnej i transgranicznej. Wszystko to ma przygotować państwa regionu do integracji europejskiej. W marcu 2008 r. Komisja Europejska przyjęła program pn. „Bałkany Zachodnie: rozszerzanie perspektywy bałkańskiej”.

Jako pierwsza przystapiła do Unii Europejskiej Słowenia 1 maja 2004 r., następnie negocjujące razem z krajami Europy Środkowej - Bułgaria i Rumunia 1 stycznia 2007 r., a jako druga spośród krajów pojugosłowiańskich Chorwacja została do Unii przyjęta dopiero 1 lipca 2013 r. Rokowania akcesyjne Chorwacji pokazały jakie ten kraj miał trudne do rozwiązania problemy będące wynikiem wojny o niepodległość.

Poważne problemy napotykają także negocjacje prowadzone z Czarnogóra, Serbią i Turcją. Krajami kandydującymi są również Albania i była Jugosłowiańska Republika Macedonii, natomiast Bośnia i Hercegowina oraz Kosowo mają status potencjalnych krajów kandydujących. Unia Europejska stosuje wobec państw tego regionu kryteria kopenhaskie, które musiały wypełnić wszystkie przyjęte dotychczas kraje kandydujące.

Są to wysokie kryteria, które trudno osiagnąć aspirującym do UE krajom Bałkanów Zachodnich. Dlatego Unia Europejska i generalnie państwa zachodnie tak dużo uwagi i zaangażowania poświęcają temu regionowi. W XXI wieku chodzi przede wszystkim o umacnianie demokracji w tych krajach, a to łącznie z perspektywą ich przyjęcia do UE daje szansę na ustabilizowanie tego regionu, który tak mocno został poszkodowany wojnami na tle etnicznym w ostatniej dekadzie poprzedniego stulecia. Trzeba także przyznać, że zachodnia polityka generalnie nie jest kontestowana przez inne państwa europejskie. Wyjątek stanowiło jedynie uznanie przez USA i większość państw członkowskich UE niepodległości Kosowa, formalnie ogłoszonej w lutym 2008 r. Rosja zdecydowanie potępiła ten krok, a następnie uznała za precedens usprawiedliwiający uznanie przez nią w sierpniu 2008 r. niepodległej Abchazji i Osetii Południowej, które 
oderwały się w latach 90. od Gruzji, a potem także dla usprawiedliwienia swojej aneksji Krymu w marcu 2014 r.

\section{Państwa bylego ZSRR}

Udzielane przez Zachód wsparcie polityczne, logistyczne i finansowe dla sił demokratycznych w państwach poradzieckich wywoływało opór nie tylko sił postkomunistycznych i miejscowych oligarchii, ale także Rosji obawiającej się ingerencji Zachodu w jej sprawy wewnętrzne i o utratę swojej strefy wpływów. Rosja jako sukcesor ZSRR niewątpliwie miała problem psychologiczny jako „upadłe mocarstwo”, stąd prezentowała duże uwrażliwienie na działania innych państw, które mogłyby godzić w jej suwerenność. Moskwa obawiała się także utraty wpływów w innych państwach powstałych na gruzach ZSRR, a zwłaszcza w krajach, które na początku lat 90. przystapiły do Wspólnoty Niepodległych Państw.

Unia Europejska od czasu rozszerzenia w 2004 r. w swojej polityce wobec państw WNP podzieliła je na trzy kategorie. Pierwszą stanowi Rosja - jako szczególny partner, określany przez lata mianem partnera strategicznego, drugą państwa objęte - proklamowaną w czerwcu 2004 r. - Europejską Polityką Sąsiedztwa, a od 2009 r. Partnerstwem Wschodnim, a trzecią kraje Azji Środkowej². Głównymi instrumentami polityki Unii wobec wszystkich państw poradzieckich są układy o partnerstwie i współpracy (Hillion, 1998, s. 399-420). Są to tzw. umowy trzeciej generacji łączące udzielanie pomocy rozwojowej z klauzulami odnoszącymi się do respektowania praw człowieka i zasad rządów prawa, a więc ,zahaczają" o kwestie będące przedmiotem zainteresowania Wspólnej Polityki Zagranicznej i Bezpieczeństwa. W 2014 r. UE podpisała z Ukrainą, Gruzją i Mołdową nowe umowy o stowarzyszeniu przewidujące także ustanowienie pogłębionej i całościowej strefy wolnego handlu (Deep and Comprehensive Free Trade Area - DCFTA).

Najważniejszym partnerem Unii Europejskiej na obszarze poradzieckim jest Federacja Rosyjska (Bryc, 2004; de Wilde, Spetschinsky, 2000). W czerwcu 1994 r. UE podpisała z Rosją na 10 lat układ o partnerstwie i współpracy; wszedł on w życie 1 grudnia 1997 r. Po dziesięciu latach próbowano go przedłużyć, ale do tego nie doszło, a układ pozostał w mocy. Nie wprowadzono więc nowych klauzul odnoszących się do współpracy w dziedzinie praworządności i praw człowieka. To okazało się korzystne dla Rosji, kiedy jej system polityczny w następnej dekadzie zaczął ewoluować w kierunku tzw. suwerennej demokracji, kwestionującej zachodnie standardy demokratyczne.

W czerwcu 1999 r. na szczycie w Kolonii przywódcy Piętnastki ogłosili pierwszą w historii wspólną strategię Unii Europejskiej, adresując ją do Rosji. Dokument ten stwierdzał m.in., że strategicznymi celami Unii Europejskiej wobec Rosji są:

- stabilna, otwarta i pluralistyczna demokracja w Rosji, rządzonej na podstawie prawa i rozwijająca gospodarkę rynkową, która będzie przynosić korzyści zarówno narodowi rosyjskiemu, jak i Unii Europejskiej;

${ }^{2}$ UE od początku traktowała trzy poradzieckie państwa bałtyckie, tj. Litwę, Łotwę i Estonię jak przynależące do Europy Środkowej i zostały one przyjęte do UE 1 maja 2004 r. 
- utrzymanie stabilności w Europie, promocja globalnego bezpieczeństwa i podejmowanie wspólnych wyzwań na kontynencie przez zintensyfikowanie współpracy z Rosja.

Wspólna strategia definiowała cele dwustronnej współpracy, a także wypracowywanie wspólnych z Rosją inicjatyw wobec krajów i regionów trzecich, w sprawach dyplomacji prewencyjnej i rozwiązywania kryzysów, zwłaszcza w sąsiedztwie Rosji, na Bałkanach i na Bliskim Wschodzie. W ten sposób program partnerstwa z Rosją rozciagnięto na wszystkie ówczesne trzy filary Unii Europejskiej (Common Strategy, 1999, s. 1-9). Zadeklarowano także rozwijanie współpracy transgranicznej i regionalnej w ramach ustanowionego w grudniu 1999 r. Północnego Wymiaru UE (Ojanen, 2000, s. 359-376; Myrjord, 2003, s. 239-257). Wspólna strategia została przewidziana na cztery lata, a w czerwcu 2003 r. przedłużono ją na kolejny rok (do 24 czerwca 2004 r.), po czym wygasła.

W tym czasie punkt ciężkości w stosunkach między UE a Rosją został przeniesiony na uzgodnione w maju 2003 r. cztery „wspólne przestrzenie”, wśród których znalazły się mające związek z promocją demokracji kwestie wolności, edukacji i kultury. W praktyce powstawały trudności z wdrażaniem w życie podpisywanych ambitnych porozumień.

Pomimo oficjalnie realizowanego strategicznego partnerstwa w stosunkach między Unią Europejską a Rosją nigdy nie brakowało problemów spornych. Jak ocenia szwedzka badaczka, partnerstwo UE z Rosją nigdy nie było ani strategiczne, ani realne, a obie strony dzieliły problemy w dziedzinach bezpieczeństwa, handlu i energii (Schmidt-Feltzmann, 2016, s. 99-103). Od początku XXI wieku niezadowolenie i krytykę niektórych państw członkowskich UE wywołuje rozwój sytuacji politycznej w Rosji, cechujący się centralizacją władzy, ograniczeniami wolności mediów i swobody działania organizacji pozarządowych. Moskwa krytykowana od lat 90. za krwawo thumiony separatyzm w Czeczenii twierdziła, że ten konflikt był jej sprawą wewnętrzną a prowadzone brutalne akcje pacyfikacyjne umiejscawiała w ramach zwalczania terroryzmu, zaś jej system polityczny ma charakter demokratyczny odpowiedni do specyfiki warunków rosyjskich.

W kręgach rządowych Rosji funkcjonuje opinia o uzasadnionych interesach w tzw. bliskiej zagranicy, rozumianej przede wszystkim jako kraje, które na początku lat 90. przystapiły do Wspólnoty Niepodległych Państw. Rosja postrzega więc próby demokratyzacji tych krajów jako dążenie do wciągnięcia ich do zachodniej strefy wpływów. Aspiracje tych społeczeństw, jak np. Ukrainy, Gruzji czy Mołdowy są ignorowane, a Rosja patrzy na wsparcie Zachodu dla sił demokratycznych poprzez pryzmat Realpolitik, w kategoriach realizmu politycznego jako wyraz dążenia do poszerzania strefy wpływów. Siły demokratyczne i organizacje pozarządowe są często postrzegane jako ugrupowania inspirowane przez Zachód, wręcz agenturalne, albo jako kierujące się liberalnymi iluzjami lub też jako ugrupowania nacjonalistyczne lub wręcz faszyzujące (na Ukrainie i w Gruzji). Dlatego w swojej polityce Rosja stara się realizować strategię izolowania państw poradzieckich od zachodnich wpływów i przyjmowania przez nie standardów demokratycznych promowanych przez UE, USA i inne podmioty, takie jak Rada Europy i OBWE. Przeciwstawia im ideę tzw. suwerennej demokracji (Ambrosio, 2009, s. 45-72). 
W 2004 roku Rosja odmówiła uczestnictwa w Europejskiej Polityce Sąsiedztwa, oczekując odrębnego traktowania i unikając sytuacji, w których byłaby postawiona na równi z innymi sąsiadami UE. Ponadto Moskwa postrzega ENP jako wyzwanie dla dominujących rosyjskich wpływów w zachodniej części obszaru WNP i na Kaukazie Południowym, co znalazło wyraz w wyraźnej krytyce tego programu przez decydentów rosyjskich w pierwszych miesiącach po jego proklamowaniu przez UE. Poważniejsze napięcia wywołało odmienne podejście obu stron do tzw. kolorowych rewolucji w Gruzji w listopadzie 2003 r. (,,rewolucja róż”), „pomarańczowej rewolucji” na Ukrainie na przełomie 2004 i 2005 r. i ,rewolucji tulipanów” w Kirgistanie w marcu 2005 r. Rosja postrzegała ruchy demokratyzacyjne w byłych republikach radzieckich z głęboką podejrzliwością, uznając, że zostały one zaaranżowane przez USA i ich europejskich sojuszników do zainstalowania prozachodnich rządów w uprawnionej rosyjskiej strefie wpływów. W rosyjskim myśleniu cele „kolorowych rewolucji” zmierzają do ograniczenia rosyjskich wpływów pod przykrywką promowania demokracji, a rewolucje te stanowią bezpośrednie zagrożenie dla zdolności Rosji do projekcji siły (Wilson, 2010, s. 21; Becker, Cohen, Kushi, McManus, 2016, s. 120). Obserwacja powstających trudności i sporów między UE a Rosją skłania niektórych autorów do formułowania opinii, że wiele porozumień politycznych zawieranych między tymi stronami ma jedynie deklaratywny charakter i nie implikuje konkretnych działań (Forsberg, 2004, s. 265). Do generalnego starcia Unii Europejskiej i Rosji doszło w czasie kryzysu ukraińskiego. Okazało się wtedy, że UE - jak twierdzi Richard Sakwa (2015, s. 26) - reprezentuje koncepcję „Szerszej Europy” (Wider Europe), a Rosja ideę „Wielkiej Europy” („Greater Europe") zakładającą budowanie luźnej Europy od Lizbony po Władywostok, z tradycyjnymi centrami wpływu w Brukseli, Moskwie i Ankarze. Okazało się wyraźnie w czasie kryzysu ukraińskiego jak odmienne są percepcje i wizje bezpieczeństwa europejskiego (Riecker, Lundby Gjerde, 2016, s. 305-306).

Warto odnotować, że silne wsparcie Zachodu było udzielane dla sił demokratycznych na Białorusi, pozostającej od 1994 r. pod autorytarnymi rządami prezydenta Alaksandra Łukaszenki. Jesienią 1996 r. doszło do poważnego przesilenia na Białorusi. Po korzystnym dla siebie referendum z 24 listopada Łukaszenka doprowadził do przedłużenia swojej kadencji o półtora roku i usunięcia z parlamentu opozycyjnych deputowanych. Opozycja polityczna na Białorusi została wyeliminowana z organów państwowych, a reżim Łukaszenki przeszedł do jawnego ograniczania swobód obywatelskich. Wywołało to duże zaniepokojenie w Polsce, zatroskanej także o los ok. 300 tys. Polaków mieszkających na Białorusi. Wtedy Warszawa zdecydowała się na prowadzenie wyraźnej polityki w regionie, inicjując pierwsze wspólne oświadczenie prezydentów Polski, Ukrainy i Litwy. Zostało ono skierowane 20 listopada 1996 r. do władz Białorusi, jako apel o rozwiązanie kryzysu politycznego środkami konstytucyjnymi oraz o poszanowanie praw obywatelskich i swobód demokratycznych, zgodnie ze standardami międzynarodowymi. Białoruś odrzuciła to oświadczenie jako ingerencję w jej sprawy wewnętrzne. Zostało ono także skrytykowane przez Rosję. Natomiast państwa zachodnie nie uznały referendum zmieniającego konstytucję Białorusi z powodu naruszeń standardów demokratycznych (Zięba, 2013, s. 242).

W czerwcu 1998 r. powstały poważne zadrażnienia w stosunkach Białorusi z krajami UE i Stanami Zjednoczonymi, po tym jak władze białoruskie nakazały dyploma- 
tom tych państw opuszczenie osiedla „Drozdy” (pod pretekstem planowanego remontu). Ambasadorzy tych państw wyjechali z Białorusi, a UE i USA nałożyły sankcje na Białoruś, polegające na wprowadzeniu zakazu wjazdu na ich terytoria białoruskich urzędników państwowych ${ }^{3}$.

Stany Zjednoczone, podobnie jak UE krytycznie zareagowały na swoisty zamach stanu na Białorusi, kiedy jesienią 2004 r. prezydent Alaksandr Łukaszenka rozwiązał parlament i przeprowadził referendum otwierające mu drogę do trzeciej kadencji. Równocześnie władze białoruskie rozpoczęły represje wobec opozycji politycznej. Unia Europejska zareagowała krytycznie i nałożyła sankcje osobowe na przedstawicieli białoruskiego reżimu. Natomiast Izba Reprezentantów Kongresu USA przyjęła Akt o demokracji na Białorusi 2004 roku, w którym potępiła antydemokratyczny kurs władz Białorusi oraz zapowiedziała nałożenie ograniczeń wizowych dla wysokich przedstawicieli władz tego kraju, zakaz współpracy z nimi i wsparcie dla białoruskiego społeczeństwa obywatelskiego (The Belarus, 2004).

W kwietniu 2006 r. sekretarz stanu USA Condoleeza Rice, przebywając na sesji Rady Północnoatlantyckiej w Wilnie, na konferencji prasowej odpowiadając na postawione jej pytania: czy Stany Zjednoczone wspierają zmianę reżimu na Białorusi? oraz czy USA popierają drogę protestów a nie wyborów, które nie będą wolne ani uczciwe?, odpowiedziała: „,ćż, jak już o tym mówiliśmy, jest kilka sposobów, aby poprzeć te wysiłki na Białorusi”. Dodała także: „,popieramy pogląd, że wybory, które odbędą się, powinny być prawdziwymi wyborami. Nie powinny to być wybory, za które trzeba się wstydzić, a wspólnota międzynarodowa powinna być przygotowana i gotowa pomóc Białorusi w przeprowadzeniu wolnych i sprawiedliwych wyborów w 2006 roku" (Press Availability, 2005). Ostatnią uwagę można było potem odnieść do wyborów odbytych 19 marca 2006 r., które według oficjalnych wyników wygrał Alaksandr Łukaszenka, który uzyskał poparcie $82,6 \%$ głosujących i został wybrany prezydentem na trzecią kadencję.

Sekretarz stanu USA określiła Białoruś mianem jednej ze „strażnic tyranii” na świecie oraz „ostatnią prawdziwą dyktaturą w Europie Środkowej”, a do grupy tej zaliczyła także Iran, Kubę, Koreę Północną, Birmę i Zimbabwe. W czerwcu 2006 r. administracja USA oświadczyła wprost, że ostatnie wybory prezydenckie na Białorusi były sfałszowane i jako takie stanowią zagrożenie dla bezpieczeństwa USA. 8 grudnia 2006 r. Izba Reprezentantów USA uchwaliła rezolucję pn. Akt o przywróceniu demokracji na Białorusi, w którym wyliczyła uchybienia ustroju Republiki Białoruś, napiętnowała działania władz w Mińsku naruszające zasady demokracji i praw człowieka oraz określiła charakter i zakres pomocy amerykańskiej dla aktywizacji społeczeństwa obywatelskiego na Białorusi, a także określiła sankcje ekonomiczne i wizowe dla przedstawicieli władz Białorusi (Full Text, 2006). W latach 2007-2008 doszło do wydaleń dyplomatów obu państw po uznaniu ich za persona non grata (Czachor, 2011, s. 245). Władze Białorusi odrzucały krytykę ze strony USA i Unii Europejskiej i wskazywały, że oznacza ona ingerencję w sprawy wewnętrzne ich kraju zmierzającą do jego destabilizacji, podobnie jak było w przypadku „kolorowych rewolucji” zwłaszcza w Gruzji i na Ukrainie. Taką samą ocenę formułowało kierownictwo Rosji, które wspierało autorytarną władzę Białorusi (Ambrosio, 2009, s. 105-109).

${ }^{3}$ Polska nie przyłączyła się do tych działań, a odwołany ambasador RP powrócił do Mińska już w styczniu $1999 \mathrm{r}$. 
Także administracja prezydenta Baracka Obamy angażowała się w promowanie demokracji w państwach poradzieckich. Na przykład w grudniu $2011 \mathrm{r}$. Izba reprezentantów USA uchwaliła Democracy and Human Rights Act, którym potępiła sposób przeprowadzenia wyborów prezydenckich na Białorusi w grudniu 2010 r., które po raz kolejny wygrał Łukaszenka, domagała się wypuszczenia na wolność wszystkich więźniów politycznych i zapewnienia wolności mediów, a także podtrzymała sankcje wizowe wobec przedstawicieli władz Białorusi (Belarus Democracy, 2011).

\section{Kryzys ukraiński}

Unia Europejska i Stany Zjednoczone wykazują szczególnie silne zaangażowanie we wspieraniu prozachodniego kursu w polityce Ukrainy. Obserwować to można było w czasie „pomarańczowej rewolucji” w tym kraju na przełomie 2004 i 2005 roku. Problematyka ta znalazła opracowanie w licznych publikacjach wydawanych na Zachodzie (Wilson, 2005; Kuzio, 2006; Ambrosio, 2009).

„Pomarańczowa rewolucja” zawiodła nadzieje Ukraińców pragnących przekształcenia ich kraju w demokratyczne państwo związane z Zachodem. Ukraina rządzona od 2010 roku przez prezydenta Wiktora Janukowycza prowadziła politykę balansowania między Rosją a Zachodem. Wprawdzie starano się o zbliżenie do Unii Europejskiej, ale w systemie politycznym kraju brakowało rozwiązań gwarantujących rządy prawa i przestrzeganie praw obywatelskich i podstawowych wolności. System ten i gospodarka kraju pozostały zdominowane przez układy oligarchiczne.

Zasadniczym krokiem na rzecz zbliżenia Ukrainy do UE miała być parafowana 30 marca 2012 r. nowa umowa o stowarzyszeniu. W umowie tej przewidziano ustanowienie bliższych związków Ukrainy z Unią Europejską, implementację większości prawa europejskiego na Ukrainie, a także ustanowienie pogłębionej strefy wolnego handlu (DCFTA). Umowa ta miała być podpisana na szczycie Partnerstwa Wschodniego Unii Europejskiej w dniach 28-29 listopada 2013 r. w Wilnie. Jednak kilka dni przed szczytem wileńskim rząd Ukrainy wydał (21 listopada) rozporządzenie o zawieszeniu przygotowań do podpisania tej umowy. Jak wyjaśnił ukraiński wicepremier Jurij Bojko, Ukraina zdecydowała się na taki krok, by uporać się z pogorszeniem relacji handlowych z Rosją oraz dlatego, że UE nie zaproponowała stronie ukraińskiej rekompensaty za wynikające z tego straty. Natomiast prezydent Janukowycz uznał, że deklaracja Unii o finansowej pomocy dla Ukrainy w zamian za podpisanie umowy była „,upokarzająca”, a przez trzy lata z rzędu była podawana Ukrainie jak ,cukierek w ładnym opakowaniu”, zaś pomoc warunkowano zobowiązaniem Ukrainy do podpisania porozumienia z Międzynarodowym Funduszem Walutowym. Stwierdził otwarcie, że nie należy Ukrainy tak poniżać, gdyż jest poważnym europejskim krajem (Janukowycz, 2013). Unia Europejska - jak ocenia znany amerykański historyk - dość lekkomyślnie i ultymatywnie żądała ,aby demokratycznie wybrany prezydent głęboko podzielonego kraju dokonał wyboru pomiędzy Europą a Rosją" (Cohen, 2014).

Decyzja rządu ukraińskiego wywołała gwałtowne protesty społeczne w Kijowie i miastach zachodniej Ukrainy. Przerodziły się one następnie w długotrwałą okupację 
centralnego placu w Kijowie, Majdanu Niepodległości, nazwanego w wyniku tych demonstracji Euromajdanem. Była to największa fala gwałtownych protestów zwolenników integracji od czasu „pomarańczowej rewolucji” (2004/2005). Początkowo demonstranci domagali się zmiany stanowiska władz Ukrainy i podpisania przygotowanej umowy. Następnie doszły żądania zmiany całego systemu władzy, odwołania rządu Mykoły Azarowa i dymisji prezydenta Wiktora Janukowycza.

W lutym 2014 roku, po odrzuceniu przez demonstrantów wynegocjowanego w wyniku mediacji ministrów spraw zagranicznych Trójkąta Weimarskiego (Niemiec, Francji i Polski) porozumienia między przywódcami opozycji politycznej a prezydentem Wiktorem Janukowyczem, doszło do swoistego zamachu stanu. Prezydent Janukowycz opuścił swój urząd i wyjechał z Kijowa, najprawdopodobniej kierując się obawą o pozbawienie go życia, a władzę przejęła opozycja działająca pod wpływem radykałów z Euromajdanu. Zachód zaniechał realizacji z trudem osiagniętego porozumienia. Po kilku dniach Rada Najwyższa Ukrainy wyłoniła nowy rząd, na czele którego stanął jeden z liderów partii Batkiwszczyna (Ojczyzna) - Arsenij Jaceniuk. Do rządu weszli działacze tej partii i nacjonalistycznej Swobody oraz przywódcy Euromajdanu. Nowy rząd zwrócił się o pomoc do państw zachodnich i ogłosił gotowość szybkiego zawarcia umowy stowarzyszeniowej z UE.

Zachód uznał nowe władze w Kijowie, a Rosja oceniła, że rządy na Ukrainie nielegalnie przejęły siły nacjonalistyczne i faszystowskie, zapowiedziała także ochronę Rosjan mieszkających na Ukrainie; politycy rosyjscy prognozowali rozpad, a nawet wojnę domową na Ukrainie. W marcu Rosja wsparła secesję Krymu, zamieszkałego w większości przez Rosjan (58,5\%). Po korzystnym dla Rosji referendum 18 marca 2014 r. prezydent Rosji Władimir Putin podpisał z władzami Krymu i Sewastopola umowę przewidująca włączenie tych dwóch podmiotów w skład Federacji Rosyjskiej.

Referendum i aneksja Krymu zostały ostro potępione przez nowe władze Ukrainy oraz państwa zachodnie, które zawiesiły udział Rosji w grupie G-8 i nałożyły pierwsze sankcje, polegające na zakazie podróżowania do USA i UE oraz zamrożenie aktywów 33 osób odpowiedzialnych za działania podważające albo zagrażające integralności terytorialnej, suwerenności i niepodległości Ukrainy. Następnie UE i USA nakładały kolejne sankcje na Rosję, chcąc zmusić ją do zaprzestania wojskowego wspierania separatyzmu wschodnich regionów Ukrainy (obwody doniecki i ługański), zamieszkałych przez ludność rosyjskojęzyczną, nieuznającą nowych władz w Kijowie. Zachód oskarżał Rosję o złamanie prawa międzynarodowego i eskalowanie konfliktu na Ukrainie. W praktyce - przy braku elastyczności Moskwy - prowadziło to do ostrej konfrontacji przypominającej czasy zimnej wojny, a Rosja nie zgodziła się na żadne ustępstwa.

Kluczowe znaczenie w polityce Zachodu miały decyzje o wciągnięciu Ukrainy do swojej strefy wpływów oraz potępianie i „karanie” Rosji za chęć niedopuszczenia do tego. 21 marca 2014 roku Unia Europejska i Ukraina podpisały w Brukseli polityczną część umowy stowarzyszeniowej. To był symboliczny gest poparcia dla wschodniego sąsiada Unii i tymczasowych władz w Kijowie w trudnym dla Ukrainy czasie (po utracie Krymu). Następnie nowe władze ukraińskie otrzymały wsparcie ekonomiczne od UE, USA i MFW. Kilka tygodni po wyborach nowego prezydenta Ukrainy Petro Poroszenki, UE podpisała 27 czerwca 2014 r. z Ukrainą handlową część umowy stowarzyszeniowej. Porozumienie to jest jednym z najbardziej ambitnych. Oferuje ono 
Ukrainie otwarcie unijnego rynku poprzez stopniowe znoszenie ceł i kwot oraz harmonizację z UE prawa i norm w różnych sektorach. Tymczasowo weszłow życie 1 stycznia $2016 \mathrm{roku}^{4}$. Generalnie w zawartym porozumieniu stowarzyszeniowym chodziło Unii Europejskiej nie tylko o związanie Ukrainy w formie DCFTA z handlem UE, normami, zasadami i prawem europejskim, ale o szersze cele polityki zagranicznej UE, a zwłaszcza jej normatywne cele polityczne, takie jak demokracja, prawa człowieka i rządy prawa (Ross Smith, 2016, s. 35).

Unia Europejska zaangażowała się na Ukrainie jako wspólnota, która zainteresowana jest poszerzaniem strefy demokracji, praw człowieka i gospodarki rynkowej. To właśnie pod wpływem starań Polski, Unia uruchomiła w 2009 r. Partnerstwo Wschodnie, a potem zdecydowała się na zawarcie nowej umowy stowarzyszeniowej z Ukrainą. Taka perspektywa oznacza nie tylko istotnej zmiany w polityce wewnętrznej Ukrainy, ale także zdecydowanie się tego państwa na przyjęcie zachodniej opcji geopolitycznej. Ta nowa orientacja w polityce zagranicznej Ukrainy - jeśli by się utrzymała - miałaby określone długofalowe konsekwencje dla Federacji Rosyjskiej, przygotowującej wówczas ustanowienie Euroazjatyckiej Wspólnoty Gospodarczej, na bazie unii celnej Rosji z Białorusią i Kazachstanem. Zresztą takie ugrupowanie stworzyła Rosja z dniem 1 stycznia 2015 r., lecz bez udziału Ukrainy.

Generalnie Unia Europejska, a także Stany Zjednoczone, zastosowały dość niejasną i niekonsekwentną politykę wobec Ukrainy. Proponowana umowa stowarzyszeniowa nie stanowiła kroku wstępnego do późniejszej akcesji tego państwa do UE. Chodziło natomiast o wsparcie i wzmocnienie na Ukrainie reform demokratycznych i rynkowych mających wciagnąć to państwo w orbitę wpływów Zachodu. Świadczy o tym bardzo zdecydowane wsparcie udzielone demonstrantom z kijowskiego Majdanu, zaakceptowanie zamachu stanu polegającego na obaleniu w lutym 2014 r. legalnie wybranego prezydenta Ukrainy, a potem wspieranie nowych nacjonalistycznych władz Ukrainy, przez Stany Zjednoczone i Unię Europejską. Dlatego zgodzić się należy z oceną Johna Mearsheimera (2014), który główną odpowiedzialnością za wywołanie kryzysu ukraińskiego obarczył Stany Zjednoczone i ich europejskich sojuszników. Odnotować także trzeba, że USA i Polska okazały się dwoma państwami najostrzej krytykującymi presję i ingerencję Rosji w sprawy wewnętrzne Ukrainy, które to zachowanie było przede wszystkim reakcją na działania państw zachodnich.

Stany Zjednoczone mocno się zaangażowały w kryzysie ukraińskim, udzielając Ukrainie politycznego wsparcia i pomocy ekonomicznej (Morelli, 2017, s. 36-41). Wcześniej dość skutecznie realizowały politykę poszerzania swoich wpływów we wschodniej części Europy. Jednak od 2008 r. zaczęły natrafiać na coraz silniejszy opór rosnącej w siłę Rosji. Wojna gruzińsko-rosyjska pokazała, że trudno im będzie doprowadzić do dalszego rozszerzenia NATO i kontynuowania promocji demokracji na wschód. Trudno bowiem uznać za racjonalny motyw chęć uczynienia z Ukrainy państwa demokratycznego i sprawnie rządzonego na wzór zachodni. Fiasko ,pomarańczowej rewolucji” z przełomu lat 2004/2005 ukazało jak jest to trudnym zadaniem,

${ }^{4}$ Umowa o stowarzyszeniu między UE a Ukrainą weszła w pełni w życie dopiero 1 września 2017 r. ze względu na sprzeciw Holandii, która zgodziła się na to dopiero o otrzymaniu zapewnienia od Rady Europejskiej, że umowa nie jest wstępem do członkostwa Ukrainy w UE, nie zobowiązuje do obrony tego kraju, ani nie otwiera unijnego rynku pracy dla Ukraińców. 
przede wszystkim ze względu na brak woli politycznej w elitach ukraińskich. Po kilku latach Zachód znowu zaczął uzasadniać swoje wsparcie dla prozachodniego wyboru samych Ukraińców, który to wybór miały potwierdzać rozpoczęte w końcu listopada 2013 roku, a trwające przez ponad rok demonstracje na kijowskim Euromajdanie.

Mearsheimer nazwał zaangażowanie USA w kryzysie ukraińskim, podobnie jak zaangażowanie Unii Europejskiej, liberalnym i mesjanistycznym urojeniem. Jeśli nawet się z nim nie zgodzimy, to i tak nasuwa się pytanie o rzeczywiste motywy zaangażowania Zachodu na Ukrainie. To natomiast może wskazać analiza interesów USA i UE w regionie. Oba te podmioty, zabiegając o przyciagnnięcie Ukrainy do siebie, zakładały włączenie jej nie do UE, ale traktowanie jako ,przedpokoju Unii”, a także niektórym politykom amerykańskim, polskim czy z krajów bałtyckich wydawało się możliwe zrealizowanie zapowiedzianego w komunikacie szczytu bukareszteńskiego z kwietnia 2008 roku przyjęcia Ukrainy do NATO. O tę drugą akcesję zabiegali zwłaszcza sąsiadujący z Rosją i odczuwający zagrożenie z jej strony nowi członkowie Sojuszu. Jeśli Ukraina pomyślnie związałaby się z Zachodem, oznaczałoby to realizację zapowiadanej przez ukraińskich ,zachidników” idei przystąpienia do UE, a także do NATO - przede wszystkim w celu uzyskania gwarancji obrony przed niegodzącą się na to Rosją. Obie opcje były bardzo trudne do zrealizowania, ale z tego w Waszyngtonie i stolicach państw środkowoeuropejskich nie zdawano sobie sprawy.

Z powyższego wynika, że Stany Zjednoczone i Unia Europejska, postanowiły wciagnnąc Ukrainę do swojej strefy wpływów. Najbardziej klarowne wyjaśnienie przyczyn wybuchu kryzysu ukraińskiego sformułował wybitny amerykański realista, Stephen Walt, pisząc: ,Jednak kryzys ukraiński nie rozpoczął się od zdecydowanego ruchu Rosji czy nawet serii nieuzasadnionych rosyjskich żądań. Zaczął się, wtedy gdy Stany Zjednoczone i Unia Europejska podjęły próbę przeciagnięcia Ukrainy z orbity Rosji do zachodniej strefy wpływów. Cel ten nie może być pojmowany abstrakcyjnie, gdyż Moskwa wyraźnie stwierdziła, że będzie walczyć 'ząb za ząb’. Przywódcy amerykańscy zignorowali te ostrzeżenia, które wynikały bardziej z rosyjskiego poczucia braku bezpieczeństwa niż z terytorialnej chciwości - i nic dziwnego, że nie zważali oni na reakcję Moskwy. Nieprzewidzenie przez dyplomację amerykańską zdecydowanej reakcji Putina było aktem niezwykłej niekompetencji i można tylko się zastanawiać, dlaczego osoby, które przyczyniły się do tej katastrofy pociagu, nie straciły swoich posad w dyplomacji” (Walt, 2015).

Wygląda na to, że Stany Zjednoczone - tracąc pozycję światowego hegemona - chciały wzmocnić swoje wpływy w Europie, wykorzystując do tego kryzys ukraiński sprowokowany przede wszystkim polityką wschodnią Unii Europejskiej. Więc USA dostrzegły teraz szansę do umocnienia swoich wpływów na obszarze b. ZSRR, powstrzymywania coraz bardziej asertywnej polityki Rosji wobec Zachodu. W trakcie kryzysu ukraińskiego USA politycznie karały Rosję za ingerencję w sprawy ukraińskie, piętnując łamanie przez nią prawa międzynarodowego i jako pierwsze państwo zastosowały sankcje ekonomiczne wobec Rosji. Chodziło im też o osłabienie Rosji jako uczestnika ugrupowania BRICS i bliskiego partnera Chin. Do tego decydując się na militarne wzmocnienie wschodniej flanki NATO dodatkowo wpływały dyscyplinująco na swoich europejskich sojuszników obawiających się Rosji, aby wysyłały swoje wojska na wschodnią flankę i zwiększały wydatki na zbrojenia. Zresztą pomocna dla 
nich była w tym zakresie polityka Polski, państw bałtyckich i Rumunii domagających się dodatkowego militarnego zabezpieczenia na wypadek konfliktu zbrojnego z Rosją. Nie wydaje się, że Waszyngton spodziewał się takiego konfliktu, ale politycznie skutecznie wykorzystywał obawy środkowoeuropejskich sojuszników, co wpływało także dyscyplinująco na sojuszników zachodnioeuropejskich, raczej niepodzielających obaw przed ewentualnym konfliktem zbrojnym z Rosją.

Generalnie rzecz ujmując należy stwierdzić, że Zachód poszerzał swoje wpływy w pozimnowojennej Europie i włączył się do rywalizacji z Rosją na obszarze poradzieckim. W 2004 r. do NATO, a następnie do Unii Europejskiej zostały przyjęte byłe republiki radzieckie Litwa, Łotwa i Estonia. Na szczycie bukaresztańskim w kwietniu 2008 r. zapowiedziano przyjęcie w przyszłości do Sojuszu Północnoatlantyckiego Gruzji i Ukrainy, a w maju 2009 r. Unia Europejska uruchomiła adresowany do sześciu krajów poradzieckich program Partnerstwa Wschodniego, zaś jesienią 2013 r. postanowiła podpisać nową umowę stowarzyszeniową z Ukrainą. To nie mogło nie niepokoić Rosji, która wskazywała, że Zachód realizuje w ten sposób swoje cele strategiczne, zmierzając do jej „okrążania”. W Moskwie się uważa, że Zachód narzuca jej sąsiadom swoje wzorce ustrojowe, pod płaszczykiem ,demokratyzacji” narusza zasady suwerennej równości i nieingerencji w ich sprawy wewnętrzne, a przez to godzi w podstawy prawne porządku międzynarodowego. Rosja, co wyraźnie wypowiedział prezydent Putin w Dumie, uzasadniając aneksję Krymu i Sewastopola, uzasadniała swoje zachowanie względami bezpieczeństwa, obawiając się przystąpienia Ukrainy do NATO. Wielu autorów wskazuje, że Rosja stosowała także dalekie od założeń klasycznego realizmu inne normatywne argumenty, takie jak: uzasadnienia względami tożsamości narodowej i czynnikami ideowymi, poszukiwaniem wewnętrznej konsolidacji politycznej i umacniania władzy w Rosji, dyskursem geopolitycznym i współpracą międzynarodową, a więc także zachodnimi i liberalnymi normami (Becker, Cohen, Kushi, McManus, 2016; Allisson, 2014).

Z powyższego wynika, że zarówno Zachód, jak i Rosja posługują się analizami sytuacji i uzasadnieniem swoich działań głównie w duchu realizmu politycznego i reguł geopolitycznych. Potwierdzają to swoim zachowaniem sami politycy mocarstw rywalizujących na obszarze poradzieckim. Przywódcy Rosji, a przede wszystkim prezydent Władymir Putin, który stara się urzeczywistniać tęsknoty Rosjan do ich ,,podniesienia z kolan" i przywrócenia dumy mocarstwowej z pozycji ich państwa. Z drugiej strony prezydent Stanów Zjednoczonych Barack Obama, po porażkach wojennych w Afganistanie (odziedziczonej po administracji G. W. Busha) i Libii, a także prestiżowych porażkach dyplomatycznych z Rosją w sprawie Syrii i Iranu, starał się wykazać oczekiwaną przez Republikanów zdolnością do działania w sprawie Ukrainy.

Samo uwzględnianie motywów, jakimi kierują się Zachód i Rosja, interweniując w sprawy wewnętrzne Ukrainy, nie wystarczy. Tutaj konieczne jest zwrócenie uwagi na pierwszą dyrektywę badawczą sformułowaną przez Morgenthau'a wskazująca, że w polityce liczą się nie tyle motywy, co skutki podejmowanych przez państwa działań i ich przewidywalne rezultaty (Morgenthau, 1954, s. 4-5). Warto, zatem zastanowić się nad konsekwencjami rywalizacji o Ukrainę dla bezpieczeństwa europejskiego. Za takie można uznać: 1) rywalizację geopolityczną, 2) konfrontację militarną w Europie, 3) osłabienie Ukrainy, 4) osłabienie bezpieczeństwa euroatlantyckiego. 
Kryzys ukraiński, zwłaszcza udział w nim Rosji, pokazuje smutną prawdę, że stabilny i sprawiedliwy porządek międzynarodowy jest zależny od współpracy wielkich mocarstw. Brak takiej współpracy daje mocarstwom „wolną rękę”, mogą łamać prawo międzynarodowe i siłą realizować swoje interesy. To Zachód uznał pierwszy, że można lekceważyć żywotne interesy narodowe Rosji. Unia Europejska, proponując Ukrainie umowę stowarzyszeniową, podjęła się operacji przypominającej rozdzielenie braci syjamskich, z których tylko jeden miał wyjść zdrowy. Rosji nie zaproponowano niczego, a do tego w lekceważący sposób argumentowano, że Rosja nie ma nic do powiedzenia w tej sprawie. Stanowiło to kontynuację polityki braku oferty dla Rosji i odpychania jej od Europy, polityki jaką zapoczątkowano po rozpadzie ZSRR. Nie powinno więc dzisiaj polityków zachodnich dziwić, że Rosja włączyła się do gry o Ukrainę. Banałem jest przypomnienie, że na Ukrainie mieszkają miliony Rosjan, a ustanowienie unii celnej między UE a Ukrainą niekorzystnie się odbija na gospodarce rosyjskiej.

\section{$* * *$}

Konkludując można zauważyć, że Zachód - który po kryzysie finansowym $2008 \mathrm{r}$. i prestiżowych porażkach dyplomatycznych, a w przypadku USA także wojskowych (Iraku i Afganistanie) - jakby strategicznie pogubił się. Nadal kontynuował oparta na liberalnej ideologii politykę promowania demokracji, bez zważania na jej geopolityczne konsekwencje. Nie mogąc się odnaleźć w dokonującej się przemianie ładu międzynarodowego, a pozostając w defensywie wobec grupy BRICS, wybrał Rosję jako swojego rywala, którego starał się zepchnąć do narożnika. Tutaj mniej chodziło o Ukrainę, o jej europejską perspektywę - bo ta była i nadal jest niejasna. Natomiast bardziej o to, że Rosja pod rządami Putina staje się coraz silniejsza i aktywniej włącza się do globalnej rozgrywki. Dlatego Zachód postanowił „wyrwać” Ukrainę spod wpływów Rosji, a gdy Moskwa się sprzeciwiła, to ją potępił i politycznie izolował oraz obłożył sankcjami, mającymi zahamować jej rozwój ekonomiczny. Zgodzić się należy z oceną Johna Mearsheimera, który główną odpowiedzialnością za kryzys ukraiński obarczył Stany Zjednoczone i ich europejskich sojuszników (Mearsheimer, 2014, s. 1) lub przynajmniej z konkluzją rosyjskich ekspertów, którzy twierdza, że zarówno Rosja, jak i Zachód ponoszą odpowiedzialność za błędy i chybione kalkulacje, które spowodowały najpoważniejszy kryzys w stosunkach wzajemnych (Arbatova, Dynkin, 2016, s. 71-90).

Prowadzona przez Zachód promocja demokracji zaczęła napotykać, zwłaszcza w drugiej dekadzie XXI wieku na silne przeciwdziałanie Rosji, co razem powodowało rosnące trudności we współpracy międzynarodowej i pogarszanie się stanu bezpieczeństwa międzynarodowego w strefie euroatlantyckiej.

\section{Bibliografia}

Allison R. (2014), Russian 'deniable' intervention in Ukraine: how and why Russia broke the rules, „International Affairs”, vol. 90, nr 6, s. 1255-1297.

Ambrosio T. (2009), Authoritarian Backlash: Russian Resistance to Democratization in the Former Soviet Union, Ashgate, Farham. 
Arbatova N. K., Dynkin A. A. (2016), World Order after Ukraine, „Survival”, vol. 58, nr 1, s. 71-90.

Becker M. E., Cohen M. S., Kushi S., McManus I. (2016), Reviving the Russian empire: the Crimean intervention through a neoclassical realist lens, „European Security”, vol. 25, nr 1, s. $123-126$.

Beichelt T. (2012), The Research Field of Democracy Promotion, „Living Reviews in Democracy” (Center for Comparative and International Studies, ETH Zurich and University of Zurich), nr 2, s. 1-13.

Belarus Democracy and Human Rights Act of 2011, 112 Congress, $1^{\text {st }}$ Session, H.R.515, http://chrissmith.house.gov/uploadedfiles/hr_515_final_text_on_passage.pdf, 19.07.2017.

Full Text of Belarus Democracy Reauthorization Act of 2006, http://belarusdigest.com/2009/03/02/ full-text-of-belarus-democracy-reauthorization-act-of-2006, 19.07.2017.

Bieleń S. (2015), Rewizjonizm geopolityczny w stosunkach międzynarodowych, „Opcja Na Prawo”, nr 3/140.

Börzel T. A., Risse T. (2009), Venus approaching Mars? The European Union as an Emerging Civilian World Power, „Berlin Working Paper on European Integration” (Freie Universität Berlin), $\mathrm{nr}$ 11, April.

Bryc A. (2004), Cele polityki zagranicznej Federacji Rosji, Wydawnictwo Adam Marszałek, Toruń.

Cohen S. F. (2014), Distorting Russia: How the American media misrepresent Putin, Sochi and Ukraine, „The Nation”, March 3.

Common Strategy of the European Union of 4 June 1999 on Russia (1999/4147/CFSP), „Official Journal of the European Communities", L 157, 24.6.1999, s. 1-9.

Czachor R. (2011), Polityka zagraniczna Republiki Białoruś w latach 1991-2011. Studium politologiczne, Wydawnictwo DWSPiT, Polkowice.

Dahrendorf R. (1990), Reflections on the Revolutions in Europe: In a Letter Intended to have been sent to a Gentleman in Warsaw, Times Books, New York.

Drygiel-Bielińska M. (2016), Unia Europejska w procesie budowania pokoju w regionie Bałkanów Zachodnich. Problemy adaptacji, Aspra, Warszawa-Siedlce.

Forsberg T. (2004), The EU-Russia Security Partnership: Why the Opportunity Was Missed, „European Foreign Affairs Review", vol. 9, Issue 2, s. 247-267.

Fukuyama F. (1992), The End of History and the Last Man, Free Press, New York.

Górka-Winter B. (2003), Polityka zewnętrzna UE wobec Bałkanów Zachodnich - wniosek Chorwacji o przystapienie do UE, „Biuletyn PISM”, nr 36 (140), 16.06.2003.

Hillion Ch. (1998), Partnership and Cooperation Agreements between the EU and the New Independent States of the Ex-Soviet Union, „European Foreign Affairs Review”, vol. 3, Issue 3, s. 399-420.

Janukowycz: deklaracja UE była upokarzajaca. Nie pozwolę, by Ukrainę ktoś poniżał, PAP, TVN24, 26.11.2013.

Kotzian P., Knodt M., Urdze S. (2011), Instruments of the EU'S External Democracy Promotion, „Journal of Comon Market Studies”, vol. 49, nr 5, s. 995-1018.

Kuzio T. (2006), The Orange Revolution at a Crossroads, „Demokratizatsiya”, vol. 14, nr 4, s. $477-492$.

Manners I. (2001), Normative Power Europe: The International Role of the EU, European Communities Studies Association Bienniel Conference, Madison, Winsconisn, USA.

Mearsheimer J. (2014), Why the Ukraine Crisis Is the West's Fault: The Liberal Delusions That Provoked Putin, „Foreign Affairs”, vol. 93, nr 5, s. 1-12.

Morelli V. L. (2017), Ukraine: Current Issues and U.S. Policy, „Congressional Research Service Report", nr 7-5, January 3. 
Morgenthau J. (1954), Politics among Nations: The Struggle for Power and Peace, Knopf, New York.

Myrjord A. (2003), Governance Beyond the Union: EU Boundaries in the Barents Euro-Arctic Region, „European Foreign Affairs Review”, vol. 8, Issue 2, s. 239-257.

Ojanen H. (2000), The EU and Its 'Northern Dimension': An Actor in Search of a Policy, or a Policy in Search of an Actor?, „European Foreign Affairs Review”, vol. 5, Issue 3, s. 359-376.

Presidency Conclusions, 21-22 June 1993, European Council in Copenhagen, SN 180/1/93 REV 1.

Press Availability at the NATO Ministerial, Secretary Condoleezza Rice, Forum Palace, Vilnius, Lithuania, April 21, 2005, US Department of State, Archive, https://2001-2009.state.gov/ secretary/rm/2005/45017.htm, 19.07.2017.

Riecker P., Lundby Gjerde K. (2016), The EU, Russia and the potential for dialogue-different readings of the crisis in Ukraine, „European Security”, vol. 25, nr 3, s. 304-325.

Ross Smith N. (2016), The EU under a realist scope: Employing a neoclassical realist framework for the analysis of the EU's Deep and Comprehensive Free Trade Agreement offer to Ukraine, „International Relations”, vol. 30(1), s. 29-48.

Sakwa R. (2015), Frontline Ukraine: Crisis in the Borderlands, I.B. Tauris, London.

Schmidt-Feltzmann A. (2016), The break down of the EU's strategic partnership with Russia: from strategic patience towards strategic failure "Cambridge Review of International Affairs", vol. 29, nr 1, s. 99-127.

The Belarus Democracy Act of 2004, Public Law 108-347, Oct. 20, 2004, http://chrissmith.house. gov/uploadedfiles/p1108347.pdf, 19.07.2017.

Walt S. M. (2015), Why Arming Kiev Is a Really, Really Bad Idea, „Foreign Policy”, February 9.

Wilde de T., Spetschinsky L. (red.) (2000), Les relations entre l'Union européenne et la Fédération de Russie, Insitute d'études européennes, Louvain-la-Neuve.

Wilson A. (2005), Ukraine's Orange Revolution, Yale University Press, New Haven-London.

Wilson J. L. (2010), The legacy of the color revolutions for Russian politics and foreign policy, „Problems of Post-Communism”, vol. 57, nr 2, s. 21-36.

Zając J. (2008), Koncepcja bezpieczeństwa USA, w: Bezpieczeństwo międzynarodowe po zimnej wojnie, red. R. Zięba, Wydawnictwa Akademickie i Profesjonalne, Warszawa, s. 43-61.

Zięba R. (2007), Wspólna Polityka Zagraniczna i Bezpieczeństwa Unii Europejskiej, Wydawnictwa Profesjonalne i Akademickie, Warszawa.

Zięba R. (2013), Polityka zagraniczna Polski w strefie euroatlantyckiej, Wydawnictwa Uniwersytetu Warszawskiego, Warszawa.

Zięba R. (2014), Międzynarodowe implikacje kryzysu ukraińskiego, „Stosunki Międzynarodowe - International Relations", t. 50, nr 2, s. 13-40.

\section{Streszczenie}

Państwa zachodnie i ich instytucje międzynarodowe (Unia Europejska i NATO), kierując się liberalną ideologią kontynuowały w XXI wieku politykę promowania demokracji, rządów prawa, praw człowieka i gospodarki rynkowej wobec byłych państw socjalistycznych na terenie Bałkanów Zachodnich oraz byłego ZSRR. Największe przeszkody stawia ich polityce Rosja, która uważa, że państwa zachodnie w rzeczywistości realizują cele poszerzania strefy swoich wpływów i narażają na uszczerbek jej interesy bezpieczeństwa. Do największej konfrontacji między Zachodem a Rosją doszło w 2014 roku na Ukrainie, kiedy UE i USA wsparły prozachodnie aspiracje nowych władz tego państwa, wyłonione w wyniku kilkumiesięcznych demonstracji ulicznych w Kijowie. Kryzys ukraiński spowodował trudności we współpracy 
międzynarodowej i pogarszanie się stanu bezpieczeństwa międzynarodowego w strefie euroatlantyckiej.

Słowa kluczowe: promocja demokracji, rządy prawa, gospodarka rynkowa, Unia Europejska, USA, NATO, Bałkany Zachodnie, państwa byłego ZSRR, Rosja, Białoruś, Ukraina

\section{Promotion of democracy by the West in Eastern Europe in the 21st century}

\section{Summary}

The Western states and their international institutions (the European Union and NATO) followed the liberal ideology in the 21 st century to continue the policy of promoting democracy, the rule of law, human rights and market economy towards the former communist states in the Western Balkans and the former USSR. The biggest impediment to their policy is Russia, which believes that Western states are actually pursuing the goals of extending their sphere of influence and compromising its security interests. The biggest confrontation between the West and Russia took place in 2014 in Ukraine, when the EU and the USA supported the pro-Western aspirations of the new authorities of the country, which emerged as a result of several months of street demonstrations in Kyiv. The Ukraine crisis has caused difficulties in international cooperation and deterioration of international security in the Euro-Atlantic zone.

Key words: promotion of democracy, rule of law, market economy the European Union, USA, NATO, Western Balkans, former USRR states, Russia, Belarus, Ukraine 
